\title{
Improving the position of the logistics performance index of Uzbekistan
}

\author{
Zokirkhan Yusufkhonov", Malik Ravshanov, Akmal Kamolov, and Elmira Kamalova \\ Tashkent State Economic University, Tashkent, Uzbekistan
}

\begin{abstract}
The purpose of this article is to propose ways to improve Uzbekistan's position in the World Bank Logistics Performance Index. The logistics performance indicator is based on a global survey of logistics specialists who may have a subjective approach to logistics systems of different countries, which leads to a potential rating. According to the account adopted by the Republic of Uzbekistan in 2018, the index is 2.58. According to the analysis, the highest DL $(20.0 \%)$ was the score received for organizing the timely delivery of goods. The lowest DL was the assessment of the work of customs authorities (13.5\%). Specific problems had been identified, and recommendations had been made to improve Uzbekistan's status. These include the effectiveness of the customs clearance process, quality of infrastructure; ease of international transport and competitive prices; staff qualifications and quality of services; Timely delivery of material flows in the procurement process.
\end{abstract}

\section{Introduction}

In the past, as a result of State transport policy, much work has been done to establish an efficient transport system that meets the economic and transport needs of the population in all transport regimes. At the same time, space communication of all regions of the country was ensured, structural reforms were carried out in the field of passenger and cargo and air transport, and conditions were created for active and effective integration into the world transport space.

At the same time, the country needs to solve several serious problems that reduce the efficiency of the transport system. This requires serious institutional changes aimed at improving the country's transport policy, ensuring a sharp increase in the quality and volume of passenger and freight traffic, reducing their cost for consumers, increasing transit traffic through Uzbekistan, and creating a competitive market given transport and logistics services, improving safety, environmental friendliness, and innovation of all modes of transport. [1]

\footnotetext{
*Corresponding author: zybuzrukov@mail.ru
} 


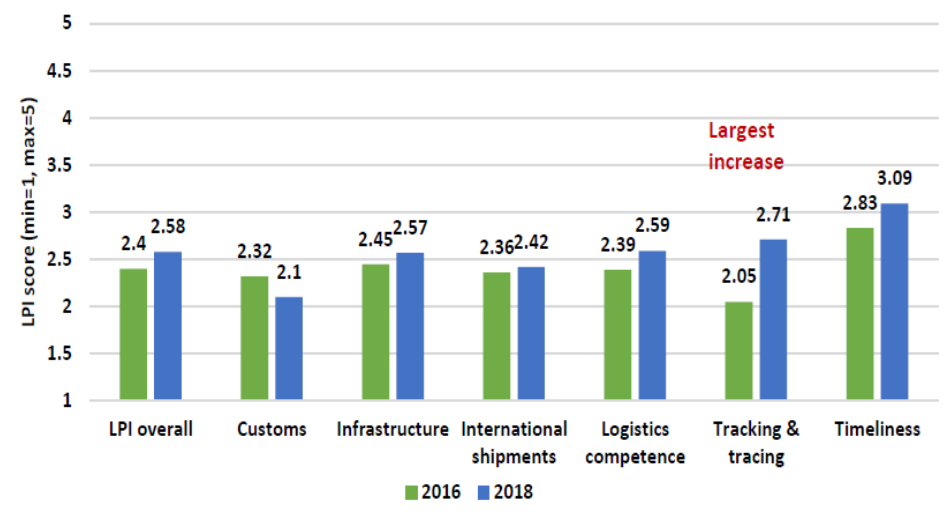

Fig. 1. Uzbekistan LPI components, 2016 and 2018

The strategy for the development of the transport system of the Republic of Uzbekistan until 2035 provides the following [2]:

- improvement of the regulatory framework in the field of transport;

- creating conditions for a sharp increase in the volume and quality of passenger and freight traffic;

- to increase coverage, to ensure equal opportunities for transport services for the population and business, regardless of the territorial location;

- development of public-private partnership formats in the field of transport infrastructure development (roads, bus and bus stations, train stations, airports);

- active implementation of innovations in the field of transport, intelligent transport systems, advanced information and communication technologies [3];

Improvement of the transport management system, establishing effective interaction between the Ministry of Transport of the Republic of Uzbekistan and sectoral transport structures in terms of tariffs and prices, forming a multimodal system of freight and passenger transportation, the formation of a single system. international transport policy, etc.;

- introduction of fundamentally new approaches to training, retraining, advanced training, selection, and advanced training of workers in the transport system in the system of educational institutions of transport;

The Logistics Performance Index (LPI) is a benchmark tool created by the World Bank to help countries identify logistics problems and what needs to be done to improve their performance [12].

The index consists of an average of six main sub-indices:

1. Efficiency of the process of cargo inspection by border control bodies, including customs points (speed, simplicity, and availability of procedures).

2. Quality of trade and transport infrastructure (railways, public roads, information technology).

3. Competitive supply prices. Ease of delivery organization.

4. Staff qualifications (operators, brokers) and quality of logistics services.

5. Ability to track goods throughout the supply chain. Its accuracy.

6. Timeliness of delivery of products and timely execution of contracts.

LPI values range from 1 (worst) to 6 (best) and increase firms' connectivity [7]. A value of less than 2.0 usually reflects several problems in a country's freight, plus delays and overcrowding a cost-effective distribution system. For example, the difference in customs entry is related to a $25 \%$ higher physical inspection rate than a single point lower LPI. This part of the article presents some of the results of a survey conducted by the World Bank in 
2018. This index is determined by the World Bank every two years, based on the feedback of stakeholders conducting logistics operations in a particular country and the world experience.

Modern logistics has a great influence on general and international processes. In the process of rapid globalization of the economy, transport management issues are very important [8]. Development of global economic integration and global service delivery systems of international supply chains in the world market. At the present stage of global development, the market is a system of exchange of goods and services between countries of export and import operations [4]. As in any market system, there is competition at the global level, between market participants or, in this case, countries; the need for global competitiveness and competitive market positions for countries through global integration has been recognized through the creation of internationally recognized instruments. Political scientists understand that countries have competitive advantages at the international level [5].

As mentioned above, one internationally recognized indicator of transport development is the infrastructure factor of the Logistics Performance Index (LPI). The first World Bank Logistics Financial Indicator (LPI) was developed in 2007 to measure the performance in terms of management and physical performance of their logistics more accurately [10-14].

\section{Methods}

The methodology used a survey format. The study involved nearly 1,000 logistics professionals from 169 countries. Germany is the country with the most efficient and highest level of LPI (Table 1). [6, 13] Table 2 presents Uzbekistan's assessments of the various components of the Logistics Efficiency Index (LPI) since 2007. The LPI methodology allows us to track the year-to-year changes in logistics processes in each country. Improving logistics performance is the foundation of economic growth and competitiveness. 
Table.1. Various factors in the 2018 Logistics Efficiency Index (LPI)

\begin{tabular}{|c|c|c|c|c|c|c|c|c|}
\hline 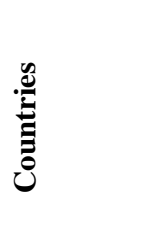 & 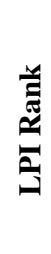 & 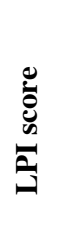 & 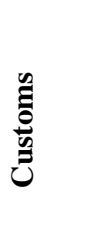 & 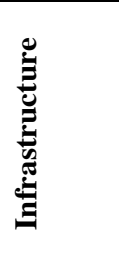 & 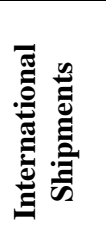 & 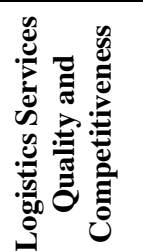 & 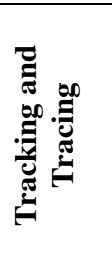 & 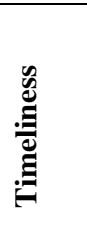 \\
\hline & & & $\begin{array}{c}\text { Rank } \\
\text { (Score) }\end{array}$ & $\begin{array}{l}\text { Rank } \\
\text { (Score) }\end{array}$ & $\begin{array}{l}\text { Rank } \\
\text { (Score) }\end{array}$ & $\begin{array}{l}\text { Rank } \\
\text { (Score) }\end{array}$ & $\begin{array}{l}\text { Rank } \\
\text { (Score) }\end{array}$ & $\begin{array}{l}\text { Rank } \\
\text { (Score } \\
\text { ) }\end{array}$ \\
\hline Germany & 1 & 4.20 & $1(4.09)$ & $1(4.37)$ & $\begin{array}{c}4 \\
(3.86)\end{array}$ & $1(4.31)$ & $\begin{array}{c}2 \\
(4.24)\end{array}$ & $\begin{array}{c}3 \\
(4.39) \\
\end{array}$ \\
\hline Singapore & 7 & 4.00 & $6(3.89)$ & $6(4.06)$ & $\begin{array}{c}15 \\
(3.58)\end{array}$ & $3(4.10)$ & $\begin{array}{c}8 \\
(4.08)\end{array}$ & $\begin{array}{c}6 \\
(4.32) \\
\end{array}$ \\
\hline Poland & 28 & 3.54 & $\begin{array}{c}33 \\
(3.25)\end{array}$ & $\begin{array}{c}35 \\
(3.21)\end{array}$ & $\begin{array}{c}12 \\
(3.68)\end{array}$ & $29(3.58)$ & $\begin{array}{c}31 \\
(3.51)\end{array}$ & $\begin{array}{c}23 \\
(3.95) \\
\end{array}$ \\
\hline Turkey & 47 & 3.15 & $582.71)$ & $\begin{array}{c}33 \\
(3.21)\end{array}$ & $\begin{array}{c}53 \\
(3.06)\end{array}$ & $51(3.05)$ & $\begin{array}{c}42 \\
(3.23)\end{array}$ & $\begin{array}{c}44 \\
(3.63) \\
\end{array}$ \\
\hline Egypt & 67 & 2.82 & $\begin{array}{c}77 \\
(2.60) \\
\end{array}$ & $\begin{array}{c}58 \\
(2.82)\end{array}$ & $\begin{array}{c}73 \\
(2.79) \\
\end{array}$ & $63(2.82)$ & $\begin{array}{c}89 \\
(2.72) \\
\end{array}$ & $\begin{array}{c}74 \\
(3.19) \\
\end{array}$ \\
\hline $\begin{array}{l}\text { Kazakhsta } \\
\mathrm{n}\end{array}$ & 71 & 2.81 & $\begin{array}{c}65 \\
(2.66) \\
\end{array}$ & $\begin{array}{c}81 \\
(2.55)\end{array}$ & $\begin{array}{c}84 \\
(2.73) \\
\end{array}$ & $90(2.58)$ & $\begin{array}{c}83 \\
(2.78) \\
\end{array}$ & $\begin{array}{c}50 \\
(3.53) \\
\end{array}$ \\
\hline Russia & 75 & 2.76 & $\begin{array}{c}97 \\
(2.42)\end{array}$ & $\begin{array}{c}61 \\
(2.78)\end{array}$ & $\begin{array}{c}96 \\
(2.64)\end{array}$ & $71(2.75)$ & $\begin{array}{c}97 \\
(2.65)\end{array}$ & $\begin{array}{c}66 \\
(3.31) \\
\end{array}$ \\
\hline $\begin{array}{l}\text { Uzbekista } \\
\mathrm{n}\end{array}$ & 99 & 2.58 & $\begin{array}{c}140 \\
(2.10)\end{array}$ & $\begin{array}{c}77 \\
(2.57) \\
\end{array}$ & $\begin{array}{c}120 \\
(2.42) \\
\end{array}$ & $88(2.59)$ & $\begin{array}{c}90 \\
(2.71) \\
\end{array}$ & $\begin{array}{c}91 \\
(3.09) \\
\end{array}$ \\
\hline
\end{tabular}

Table. 2. Logistics Efficiency Index (LPI) for 2007-2018 Results of Uzbekistan on various factors

\begin{tabular}{|c|c|c|c|c|c|c|}
\hline Years & Customs & $\begin{array}{l}\text { Infrastr } \\
\text { ucture }\end{array}$ & $\begin{array}{l}\text { International } \\
\text { shipments }\end{array}$ & $\begin{array}{c}\text { Logistics Services } \\
\text { Quality and } \\
\text { Competitiveness }\end{array}$ & $\begin{array}{c}\text { Tracking } \\
\text { and } \\
\text { Tracing }\end{array}$ & Timeliness \\
\hline & $\begin{array}{c}\text { Rank } \\
(\text { Score })\end{array}$ & $\begin{array}{l}\text { Rank } \\
\text { (Score) }\end{array}$ & $\begin{array}{l}\text { Rank } \\
\text { (Score) }\end{array}$ & Rank (Score) & $\begin{array}{l}\text { Rank } \\
\text { (Score) }\end{array}$ & $\begin{array}{l}\text { Rank } \\
\text { (Score) }\end{array}$ \\
\hline 2007 & $\begin{array}{c}136 \\
(1.94)\end{array}$ & $\begin{array}{c}124 \\
(2.00)\end{array}$ & $133(2.07)$ & $118(2.15)$ & $123(2.08)$ & $112(2.73)$ \\
\hline 2010 & $\begin{array}{c}107 \\
(2.20)\end{array}$ & $\begin{array}{c}70 \\
(2.54)\end{array}$ & $83(2.79)$ & $89(2.50)$ & $63(2.96)$ & $50(3.72)$ \\
\hline 2012 & $\begin{array}{c}118 \\
(2.25)\end{array}$ & $\begin{array}{c}120 \\
(2.25)\end{array}$ & $127(2.38)$ & $117(2.39)$ & $105(2.53)$ & $101(2.96)$ \\
\hline 2014 & $\begin{array}{c}157 \\
(1.80)\end{array}$ & $\begin{array}{c}148 \\
(2.01)\end{array}$ & $145(2.23)$ & $122(2.37)$ & $77(2.87)$ & $88(3.08)$ \\
\hline 2016 & $\begin{array}{c}114 \\
(2.32)\end{array}$ & $\begin{array}{c}91 \\
(2.45)\end{array}$ & $130(2.36)$ & $116(2.39)$ & $143(2.05)$ & $114(2.83)$ \\
\hline 2018 & $\begin{array}{c}140 \\
(2.10)\end{array}$ & $\begin{array}{c}77 \\
(2.57)\end{array}$ & $120(2.42)$ & $88(2.59)$ & $90(2.71)$ & $91(3.09)$ \\
\hline
\end{tabular}

The data in Table 2 assess the change in the LPI score from the previous period. For Uzbekistan, these changes are positive and characterize the improvement in logistics indicators until 2018. This LPI highlights the fact that various LPI factors in Uzbekistan are improving in 2018. This is the result of a comparison with all previous years. [14,18,19]

In the 2018 World Bank survey questionnaire, experts were asked the following questions:

1. Your position in the company. 
2. What level do you operate?

3. How many employees are in your company?

4. Transportations with which you most often work:

5. Direction in which your company conducts its main activity:

6. Basic model of your transportation:

7. What countries or regions do you work mostly at?

8. In what country do you work?

9. Evaluate the process of customs clearance of cargo in each of the previously selected countries.

10. Assess the quality of the trade and transport infrastructure (ports, railways, highways, information technology, etc.).

11. Rate the ease of organizing delivery and the competitiveness of the prices of carriers.

12. Assess the quality of logistics services and the competence of the staff.

13. Evaluate the possibility and accuracy of cargo tracking when shipped to previously selected countries.

14. Rate the punctuality of delivery and the possibility of delivery "Just in Time."

15. How often do partners from selected countries ask to reduce the harmful impact on the environment during transportation (use of vehicles with low emissions, selection of bypass roads, etc.)?

16. Based on your experience in international logistics, estimate the number of fees in your country:

17. Please rate the quality of transport infrastructure in your country (ports, highways, airports, information technology):

18. Evaluate the competence of employees and the quality of service in the logistics of your country (very low, low, medium, high, very high):

19. Evaluate the effectiveness of these processes in your country (almost never, rarely, sometimes, often, constantly).

20. Compared to 2015, what improvement or deterioration do you feel in your country, in the following aspects (worsened, unchanged, improved, improved a lot):

21. Compared to 2015, assess the development in the following sectors of your country (decreased significantly, decreased, did not change, increased, increased strongly):

22. What scheme of delivery of goods while exporting from your country do you use?

23. What scheme of delivery of goods while importing into your country do you use?

24. Do you (as a logistics provider) have indicators of the level (quality) of customer service? If so, what percentage of shipments are going to your country that meets your requirements?

25 . How many government agencies or departments interact with your cargo are in your typical job? When exporting/importing?

26. How many forms do you need to fill out to export/import a product from your country?

27. How long does it take on average between accepting a customs declaration and notification of customs clearance in your country?

28. What is the main method of physical examination of goods used by your customs office? (yes, no, I don't know).

29. What is the average percentage of consignments, diagnostic scans (such as X-ray scans) when imported into your country?

30. What percentage of cargo is screened more than once when imported into your country?

\section{Results and Discussion}


Analysis of logistic indicators of Uzbekistan

The last score received by the Republic of Uzbekistan in 2018 was 2.58, namely:

- Assessment of the work of customs -2.1 or $13.5 \%$ in total

- Transport and trade infrastructure -2.57 or $16.6 \%$ in total

- The cost of international transport -2.42 or $15.63 \%$ in total

- Competence of employees and quality of services -2.59 or $16.73 \%$ in total

- Ability and accuracy of cargo tracking - 2.71 or $17.5 \%$ in total

- Timeliness of delivery -3.09 or $20 \%$ of the total amount

Let's compare all indicators for period of $2007-2018$.

Thus, Uzbekistan received the maximum score (2.79) in 2010 and the minimum (2.16) in 2007.

In 2018, Uzbekistan received an average of 2.58 points, to which the largest share (as in other years) was contributed by the point received for organizing the timely delivery of goods.

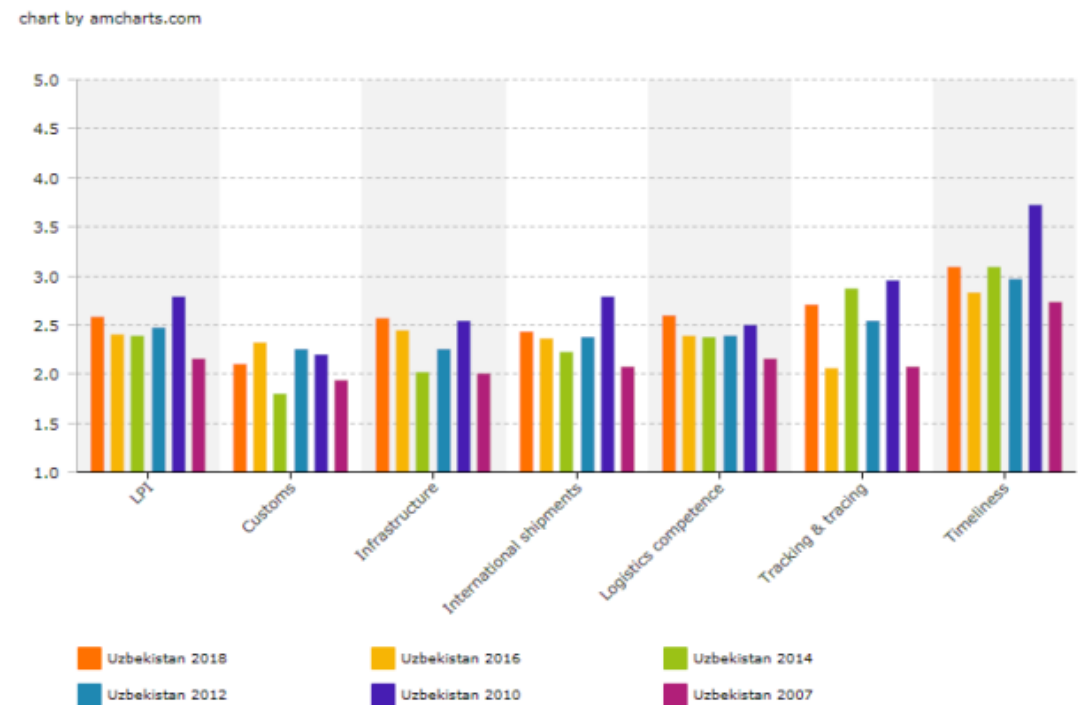

Fig. 2. Dynamics of Uzbekistan's positions in the ranking of logistics performance

Thus, based on the above, you can take the following ways to solve the tasks:

The efficiency of the customs clearance process:

- it is necessary to actively introduce electronic document management tools. to reduce as much as possible the time of transfer of a document between instances, as well as the number of instances and supervisory authorities themselves;

- improve and refine the Single Window mechanism. Integrate this functionality into the general information base of public services. Reduce the barrier to entry for small businesses;

- conduct training to explain the work of new systems and increase information literacy of people;

- develop a mechanism for closer interaction with customs authorities in Asia and Europe;

- to speed up the time of crossing border points by road at times and bring it to the average for Europe. Introduce an electronic queuing mechanism, organize parking lots for heavy vehicles and related infrastructure; 
- introduce a mechanism for smart consolidation of goods in warehouses, thereby reducing the time for idle time for loading/unloading. Introduce a mechanism of penalties for drivers who come to pick up the load at the wrong time; [13]

- carry out legislative reform, increasing the responsibility of customs officials for official crimes;

- conduct constant work with statistical data, anticipating possible flows and volumes of cargo;

- introduce a clear and simple evaluation system of indicators to control the work of both the customs terminal as a whole and each employee in particular;

- simplify the inspection procedure, do not open containers with cargo without special reason;

- if possible, purchase X-ray equipment to inspect containers without opening with automatic identification of prohibited goods.

Quality of infrastructure [16,17]:

- renew the fleet of freight vehicles. when updating, take into account euro standards;

- development of roadside service. Construction of gas stations along highways, parking lots within the city;

- development of a strategy for the development of freight traffic;

- consolidation of work of small carriers;

- simplification of visa regime;

- reducing the cost and improving the quality of fuel, especially outside of large cities;

- increase the coverage area of cellular communication of the 3rd and 4th generation. Covering remote regions;

- focus on developing infrastructure in countries such as Canada, Indonesia, Morocco, Thailand, India.

Ease of organizing international transport. Price competitiveness:

- Accelerate the coordination of transportation plans

- Have at your disposal rolling stock for various types of transportation

- Eliminate clearance areas that give rise to corruption

Competence of employees and quality of services:

- selection of qualified logistics personnel;

- upgrading the qualifications of existing employees;

- recruitment of logistics managers with experience in other countries;

- upgrading the qualifications of existing logistics supervision staff;

- development and improvement of the quality of vocational education in logistics;

- launch of private courses and certifications in the field of logistics;

- introduction of logistics education at universities;

- certification of logistics skills;

- enhancing the role of international and republican associations in the functioning of the logistics sector;

- increasing the attractiveness of the industry for young professionals;

- carrying out competent work on the selection of personnel.

Ability to track cargo:

- improve the accuracy of tracking cargo in space. Purchase modern GPS, GLONASS receivers

- equip vehicles with additional monitoring tools. Such as control of fuel consumption, control of the driver's work schedule on the way.

- equipment of vans and containers with tightness sensors, electronic seals

- fastening of special stickers - indicators on the load, to monitor the load for overloads, impacts, overturns

Timeliness of cargo delivery: 
On this point, Uzbekistan received a relatively high assessment, as a result of which it does not require separate measures, and it is necessary to implement plans in the previous directions so that they have a positive effect and on this criterion.

For more efficient use of the transport and transit potential of the country and reducing the costs of subjects of foreign economic activity of Uzbekistan, it is necessary to create conditions for closer integration of the national transport system with new international transport corridors.

It requires the followings:

- the formation of new transport corridors "Uzbekistan - Turkmenistan - Iran - Oman" and "Termez-Mazar-i-Sharif - Andkhoy - Herat - Iran" and the intensification of consideration of the issue of building a railway Herat - Andkhoy - Mazar-i-Sharif;

- creation of the international railway corridor "Europe-Uzbekistan-China" through the implementation of the project for the construction of the railway "Uzbekistan-KyrgyzstanChina";

- an increase in checkpoints at the customs borders of Uzbekistan to remove congestion at existing checkpoints;

- increasing the transit attractiveness of Uzbekistan by improving and simplifying customs procedures and developing logistics services, including modern information systems

management of container terminals, accounting for the container fleet, the movement of containers, control over the procedure for processing shipping documents, etc.

Strengthening political interaction in this area with China and Russia and neighboring states of Central Asia, which will contribute to the development of regional transport infrastructure and the achievement of agreements on cross-border cooperation, taking into account the national interests of Uzbekistan.

It is important to note here that the effectiveness of achieving the above goals will strongly depend on the degree of participation of all countries in the region in the processes of harmonization of customs and cross-border procedures.

\section{Conclusions}

A strong logistics industry is extremely crucial for supporting economic growth in Uzbekistan. Thus, to establish and develop this competitive sphere, Uzbekistan should investigate every tiny factor and causes of challenge. This would involve so many specific approaches, including analyzing major obstacles affecting the improvement of marketing, defining the way of cooperation and integration between government and private agencies, simplifying transit processes, increasing coordination among Uzbek and foreign logistics companies, developing the quality of customs administration, attracting investors to private sectors, reconstructing the infrastructure of roads and highways and finally reducing the power of monopoly in transportation. As long as those abovementioned approaches are implemented outstandingly by Uzbek Government, it will perfectly lead to the development of a competitive logistics industry.

\section{References}

1. Resolution of the President of the Republic of Uzbekistan dated February On additional measures to improve the rating of the Republic of Uzbekistan in the annual report of the World Bank and International Finance Corporation" Doing Business ". (5), pp-4160 (2019). 
2. Samatov G.A, Samatov R.G. Ways to improve Uzbekistan's position in the logistics efficiency

http://www.aitm.uz/upload/iblock/db9/db9ff7bc0495bd983a27fde53d4e00c4.pdf

3. Arvis, J.-F., Ojala, L., Wiederer, C., Shepherd, B., Raj, A., Dairabayeva, K., \& Kiiski, T. Connecting to Compete 2018: Trade Logistics in the Global Economy. World Bank. https://doi.org/10.1596/29971 (2018).

4. Azam, M., Khan, A. Q., Abdullah, H. B., \& Qureshi, M. E. The impact of CO2 emissions on economic growth: Evidence from selected higher $\mathrm{CO} 2$ emissions economies. Environmental Science and Pollution Research, 23(7), 6376-6389. https://doi.org/10.1007/s11356-015-5817-4. (2016).

5. Beysenbaev, R., \& Dus, Y. Proposals for improving the Logistics Performance Index. The Asian Journal of Shipping and Logistics, 36 (1), pp 34-42. https://doi.org/10.1016/j.ajsl.2019.10.001. (2020).

6. Bookbinder, J. H., \& Tan, C. S. Comparison of Asian and European logistics systems, International Journal of Physical Distribution \& Logistics Management, 33 (1), pp 3658. https://doi.org/10.1108/09600030310460990 (2003).

7. Bringula, R. P., Moraga, S. D., Catacutan, A. E., Jamis, M. N., \& Mangao, D. F. Factors influencing online purchase intention of smartphones: A hierarchical regression analysis. Cogent Business \& Management, 5 (1), 1496612. https://doi.org/10.1080/23311975.2018.1496612 (2018).

8. Brooks, D. H. Linking Asia's trade, logistics, and infrastructure (Working Paper 128). ADBI Working Paper. https://www.econstor.eu/handle/10419/53651 (2008).

9. Çemberci, M., Civelek, M. E., \& Canbolat, NThe Moderator Effect of Global Competitiveness Index on Dimensions of Logistics Performance Index. Procedia Social and Behavioral Sciences, 195, pp 1514-1524. https://doi.org/10.1016/j.sbspro.2015.06.453. (2015).

10. Chen, Y., Wang, J., \& Yu, Y. A Study on Consumers' Willingness to Pay for Remanufactured Products, A Study Based on Hierarchical Regression Method. Frontiers in Psychology, 10. https://doi.org/10.3389/fpsyg.2019.02044 . (2019)

11. Cohen, J., \& Cohen, P. Applied Multiple Regression/Correlation Analysis for the Behavioral Sciences. Journal of the American Statistical Association, 80 (390), pp 485-486. https://doi.org/10.2307/2287930. (1985).

12. Faisol, N., Jaafar, H. S., \& Bakar, M. A. A. Logistics Performance Measurements, A Descriptive Analysis.

https://www.academia.edu/23411953/Logistics_Performance_Measurements_A_Descriptiv e_Analysis. (2014).

13. Gani A. The Efficiency of Customs Clearance Processes Can Matter for Trade. International Advances in Economic Research, 22 (1), pp 109-110. https://doi.org/10.1007/s11294-015-95566. (2016).

14. García, C. B., García, J., Martín, M. M. L., \& Salmerón, R. Collinearity: Revisiting the variance inflation factor in ridge regression. Journal of Applied Statistics, 42 (3), pp 648-661. https://doi.org/10.1080/02664763.2014.980789, (2015).

15. Kwok, A. O. J. ASEAN Logistics Performance and Bilateral Trade in the Global Supply Chain. In J. Xu, F. L. Cooke, M. Gen, \& S. E. Ahmed (Eds.), Proceedings of the Twelfth International Conference on Management Science and Engineering Management Springer International Publishing. (pp. 1375-1382). https://doi.org/10.1007/978-3-319-93351-1_107. (2019).

16. Marcouiller, D. (2005). Migration Decision-making: A Hierarchical Regression Approach. Journal of Regional Analysis \& Policy, 35 (2), pp 11-22. 
17. Martí, L., Puertas, R., \& García, L. The importance of the Logistics Performance Index in international trade. Applied Economics, 46 (24), pp 2982-2992. https://doi.org/10.1080/00036846.2014.916394. (2014).

18. Miles, J. Tolerance and Variance Inflation Factor. In Encyclopedia of Statistics in Behavioral Science. American Cancer Society. https://doi.org/10.1002/0470013192.bsa683. (2005).

19. Munim, Z. H., \& Schramm, H.-J. The impacts of port infrastructure and logistics performance on economic growth: The mediating role of seaborne trade. Journal of Shipping and Trade, 3 (1), https://doi.org/10.1186/s41072-018-0027-0. (2018).

20. Notteboom, T. E., \& Rodrigue, J.-P, Port regionalization: Towards a new phase in port development. Maritime Policy. (2005). 